\title{
First report of Austroporus doctus (Blackburn) from New Zealand and description of its larva (Coleoptera: Phalacridae)
}

\author{
Matthew L. Gimmel ${ }^{1} \&$ Richard A.B. Leschen ${ }^{2}$ \\ 1 Santa Barbara Museum of Natural History. Santa Barbara, California, United States. \\ ORCID: http://orcid.org/0000-0001-7851-5088. E-mail: mgimmel@sbnature2.org (corresponding author) \\ 2 New Zealand Arthropod Collection (NZAC). Manaaki Whenua Landcare Research. Auckland, New Zealand. \\ ORCID: http://orcid.org/0000-0001-8549-8933.E-mail: leschenr@landcareresearch.co.nz
}

\begin{abstract}
The Australian species Austroporus doctus (Blackburn) is reported from New Zealand for the first time. Adults are illustrated and diagnosed, and late-instar larvae are fully described and illustrated. In addition, a summary of prior larval descriptions of Phalacridae is provided. This represents the first description of the morphology and habitat of the larvae within the genus Austroporus Gimmel and the Olibroporus-group of genera. Austroporus doctus is native to eastern Australia, where adults are distinguished from similar species by characters of the male genitalia and by a suite of external morphological features. There are no native members of Phalacridae known from New Zealand, but $A$. doctus represents the second introduced and established species there. A key is given to differentiate adult and larval $A$. doctus from the other introduced New Zealand species, Phalacrus uniformis (Blackburn).
\end{abstract}

Key-Words. Cucujoidea; Immature stages; Australian region; Shining mold beetles.

\section{INTRODUCTION}

The beetle family Phalacridae, with 33 genera and about 650 described species (Gimmel, 2013, 2017, personal data), is distributed nearly worldwide. Notably, no phalacrids have been reported from Chile, and no native phalacrids have been reported from New Zealand. One introduced subspecies, Phalacrus uniformis frigoricola Thompson \& Marshall, 1980, was reported to be established in the North Island (Thompson \& Marshall, 1980).

Adults and larvae of most members of the family appear to be associated with fungi, though a significant number of species are associated with pollen of seed plants as adults, while their larvae apparently feed on plant fluids (Steiner, 1984; Gimmel, 2013). Phalacrus u. frigoricola was reported to feed within the galls of Uromycladium notabile (Ludwig) McAlpine and U. acaciae (Cooke) Sydow on Acacia mearnsii DeWildemann in New Zealand (Thompson \& Marshall, 1980).

Recently, fresh adult and larval specimens of a phalacrid with a remarkably similar habitat to $P$. $u$. frigoricola, occurring with the seed pods of Acacia longifolia (Andrews) Willd., were found in Northland, New Zealand. However, the adults were readily recognized as a different species based on coloration. We take the opportunity here to identify the species involved and to describe its larva.

The genus Austroporus Gimmel belongs to the Olibroporus-group of genera as defined by Gimmel (2013, 2017), which includes the Australasian Austroporus, the Western Australian Platyphalacrus Gimmel, and the New World Olibroporus Casey (including Pycinus Guillebeau). The immature stages of members of this group have not previously been described.

\section{MATERIAL AND METHODS}

This study was based on the detailed examination of 12 larvae and 65 adult specimens of Austroporus from the following institutions: ANIC: Australian National Collection of Insects, Canberra, Australia; BMNH: The Natural History Museum, London, UK; MLGC: Matthew L. Gimmel collection, Santa Barbara, California; NZAC: New Zealand Arthropod Collection, Manaaki Whenua, Auckland, New Zealand.

Double slashes ("//") are used to separate information from separate labels, and single slashes ("/") used to separate lines within a label for verbatim label data on the syntype. 
Dry-mounted adults were imaged using a Canon EOS 7D with an MPE $65 \mathrm{~mm}$ lens mounted on a Cognisys StackShot. Specimens were examined and aedeagal images were obtained using a Zeiss SteREO Discovery.V20 with planapochromatic lenses and a $3.5 \times$ objective with $10 \times$ oculars. All source images were stacked in Helicon Focus 6.8.0. The aedeagus was dissected using warm distilled water, then the abdomen was treated in a $10 \%$ potassium hydroxide solution. Genital sclerites were imaged in glycerol on a microscope slide, then re-mounted with pinned specimens on rectangular clear plastic cards in a drop of dimethylhydantoin formaldehyde resin. For larvae, images were captured through a Leica MZ-12.5 stereomicroscope, a Leica DC500 digital camera, and Helicon Focus software. Further photo processing was done using the software packages Adobe ${ }^{\circledR}$ PhotoShop ${ }^{\circledR}$ and CorelDRAW ${ }^{\circledR}$ graphics suite. Processing of line drawings was done using Adobe ${ }^{\circledR}$ Illustrator.

\section{RESULTS AND DISCUSSION}

\section{Subfamily Phalacrinae Leach, 1815 \\ Olibroporus-group (sensu Gimmel, 2013) Austroporus Gimmel, 2013}

\section{Austroporus doctus (Blackburn, 1895)}

Parasemus doctus Blackburn, 1895: 212; Lea, 1932: 481. Austroporus doctus: Gimmel, 2013: 61.

Type locality: Blue Mountains, New South Wales, Australia (according to original description). One syntype examined, card-mounted, unsexed, with the data " $T$ / 5947 / N.S.W. [red handwriting] // Type / H.T. // Australia. / Blackburn Coll. / B.M. 1910-236. // Parasemus / doctus, Blackb. [handwritten]", deposited in BMNH. Another syntype specimen was apparently mounted on the same card, but was not located (M. Barclay, pers. comm.).

Adult material examined: NEW ZEALAND: Northland: Waiharara, Big Flat Road, $34.919^{\circ} \mathrm{S}, 173.180^{\circ} \mathrm{E}$, ex Acacia longifolia, 11 December 2018, leg. Richard Hill (16, NZAC; 2, ANIC; 5, MLGC). AUSTRALIA: Australian Capital Territory: $5 \mathrm{~km}$ NE of Canberra, sheltering and in Uromycladium galls on Acacia, 22 August 1993, S. Neser (8, ANIC); Wombat Creek, 6 km NE of Piccadilly Circus, 750 m, flight intercept window/trough trap, January 1984, Weir, Lawrence, Johnson (1, ANIC); New South Wales: 3 km S of Mongarlowe, $35^{\circ} 27^{\prime} \mathrm{S}, 149^{\circ} 57^{\prime} \mathrm{E}$, December 1987, M.E. Irwin (1, ANIC); Border Range National Park, Lophostemon Falls, ex Acacia melanoxylon, 22 November 1986, C. Reid (1, ANIC); Brisbane Water National Park, Warrah Trig, 21 January 1986, D.B. McCorquodale (3, ANIC); Kioloa State

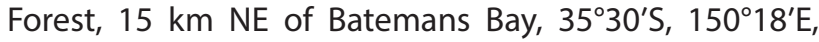
flight intercept trap, February 1987, M.G. Robinson (1, ANIC); Lorien Wildlife Refuge, $3 \mathrm{~km} \mathrm{~N}$ of Lansdowne/ Taree, ex r/f margin, Malaise trap, 18-25 October 1987, G. Williams (1, ANIC); Wild Cattle Creek State Forest, Platypus Flat, 16 November 1982, J. Doyen (13, ANIC);
Yuraygir National Park, Station Creek, 20 November 1982, J. \& E. Doyen (2, ANIC); Queensland: 2 km SE of Paluma, $18^{\circ} 59^{\prime} \mathrm{S}, 146^{\circ} 09^{\prime} \mathrm{E}$, at light, rainforest, 17 January 1970, Britton \& Misko (3, ANIC); Ewan Road, ca. 8 km W of Paluma, at light, 8 January 1967, J.G. Brooks (1, ANIC); 13 km NW of Kuranda, 6 December 1982, J. Doyen (1, ANIC); Black Mountain Road, $10 \mathrm{mi} \mathrm{N}$ of Kuranda, 8 March 1969, J.G. Brooks (1, ANIC); Cunninghams Gap National Park, 4 km W of Summit, 27-28 November 1982, J. Doyen (1, ANIC); Bunya Mountains, $3 \mathrm{~km}$ from summit on Kingaroy Road, $26^{\circ} 50^{\prime} \mathrm{S}, 151^{\circ} 33^{\prime} \mathrm{E}$, at light, 6 January 1970, Britton, Holloway, Misko (1, ANIC); 4 km E of Mount Mowbullan, ex low bushes, 18-21 November 1986, C. Reid (1, ANIC); Pine Creek, near Bundaberg, 10 December 1975, H. Frauca (1, ANIC).

Larval material examined (all late instar). NEW ZEALAND: Northland: Henderson Bay, $34.744^{\circ} \mathrm{S}$, $173.031^{\circ} \mathrm{E}$, ex Acacia longifolia, 11 December 2018, leg. Richard Hill (9 in EtOH, 1 slide-mounted, NZAC; 2 in glycerol, MLGC).

Adult diagnosis: Austroporus doctus may be recognized among other species of the genus by the relatively small size (1.9-2.7 mm), elytral disc (Figs. 1, 3) with red V-shaped maculation, hind femur without subapical expansion (Fig. 2), elytra with diffraction grating, grooves around the dorsal margin of the eye (Fig. 4), dense setation on the central part of the prosternum (much denser than on metaventral process), and by the male genitalia (Figs. 5-8). A probably undescribed species of Austroporus from several localities in eastern Cape York Peninsula in Queensland (20 specimens examined, deposited in ANIC) is similar in appearance, but with the red maculation concentrated around the elytral suture and not extending onto the elytral disc, and markedly different male genitalia.

Larva description: Length: 3.46-4.92 mm. Body (Fig. 14) dorsoventrally compressed, with thoracic segments slightly narrower than abdominal segments, all thoracic tergites and abdominal tergites I-VII weakly pigmented; abdominal segment I slightly wider than thoracic segments, narrower than abdominal segment II, segments II-VI about equal in width, segment VII narrower than VI; each abdominal segment laterally rounded and somewhat lobate, widest just posterior to middle; segment VIII elongate, gradually narrowed posteriorly, more darkly sclerotized near posterior margin; segment IX very short, bearing prominent, darkly pigmented, paired urogomphi; vestiture of sparsely distributed long setae.

Head (Figs. 15-17) transverse (about 0.6 times as long as wide), emarginate posteriorly above occipital foramen; ecdysial lines widely separate at base, frontal arms lyriform. Median endocarina weakly indicated, short, unpaired. Stemmata (Fig. 17) relatively large, not well separated, with well-developed lenses, 4 or more on each side, an anterior curved row of two or three, and two lying behind them, located on elevated area. Antenna (Fig. 9) about one-third as long as head width, 
located on a weakly raised, membranous antennifer; ratio of antennomere lengths 1: 1.8: 1.1; first antennomere 0.88 times as long as wide, second less than 2 times as long as wide and slightly narrower than first; third about 2 times as long as wide and about half as wide as the second; antennomeres 2 and 3 each bearing 3 long setae, positioned in transverse row in apical half on antennomere 2 , positioned in small triangle subapically on antennomere 3; sensorium small, elongate-conical with apex acute, on oblique apical aspect of antennomere 2; antennal insertions separated from mandibular articulations by strip of cuticle about half the diameter of antennifer. Frontoclypeal suture absent. Labrum fused to head capsule, strongly transverse, sides arcuate and apex truncate. Mandibles (Figs. 12,13) symmetrical, short and transverse, slightly wider than long, without
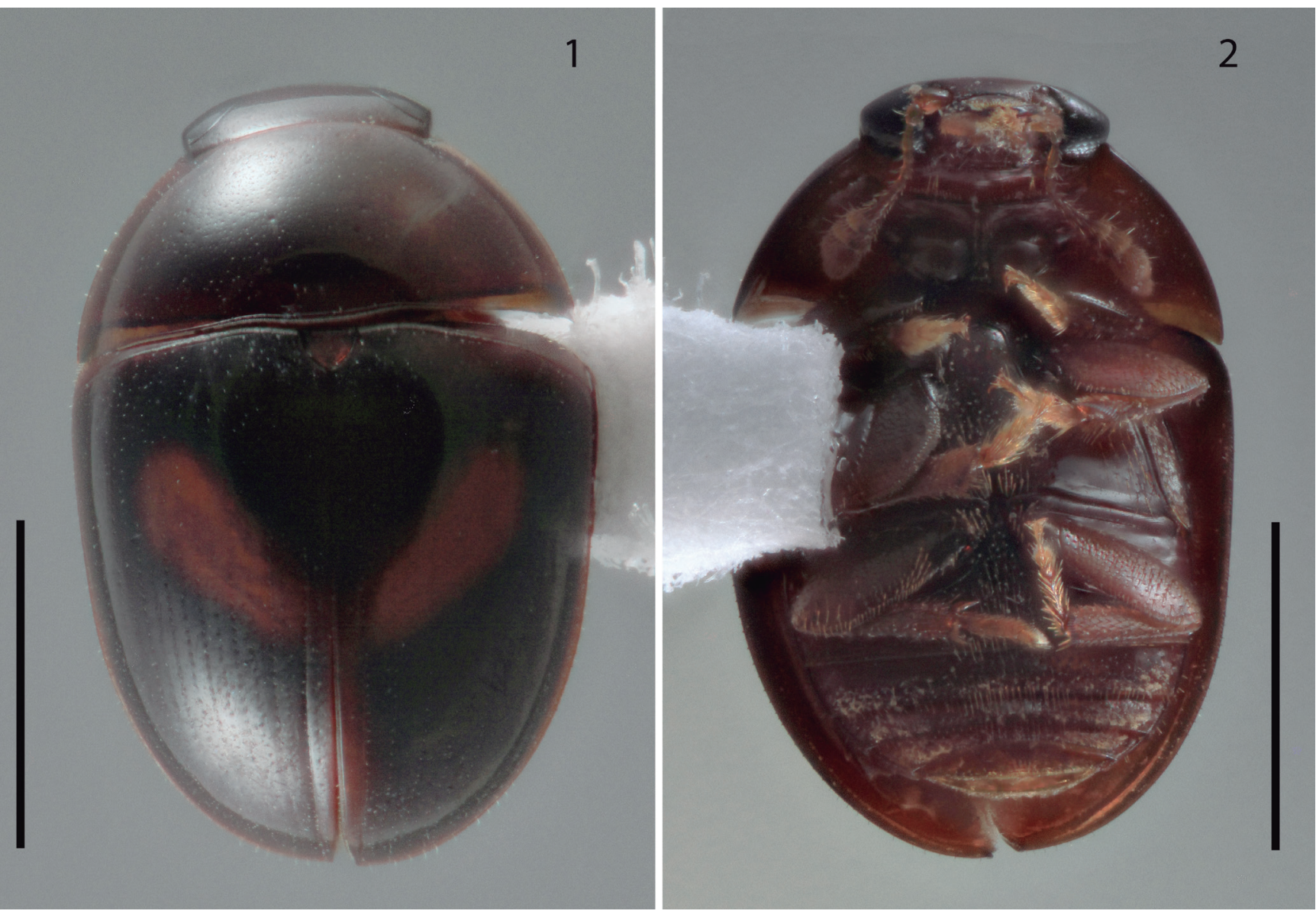

Figures 1-2. Austroporus doctus (Blackburn), adult habitus. (1) Dorsal, (2) ventral. Scale bars: $1 \mathrm{~mm}$.

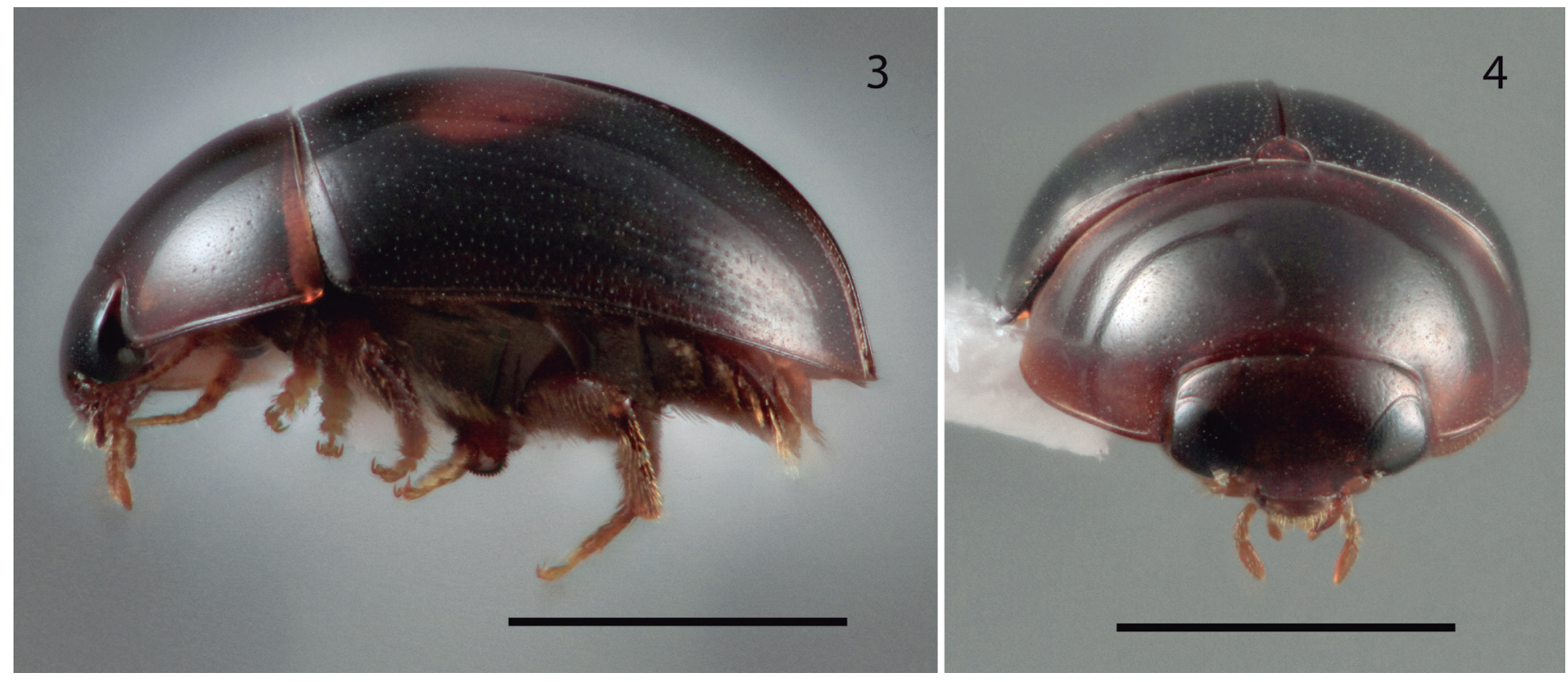

Figures 3-4. Austroporus doctus (Blackburn), adult habitus. (3) Lateral, (4) frontal. Scale bars: 1 mm. 


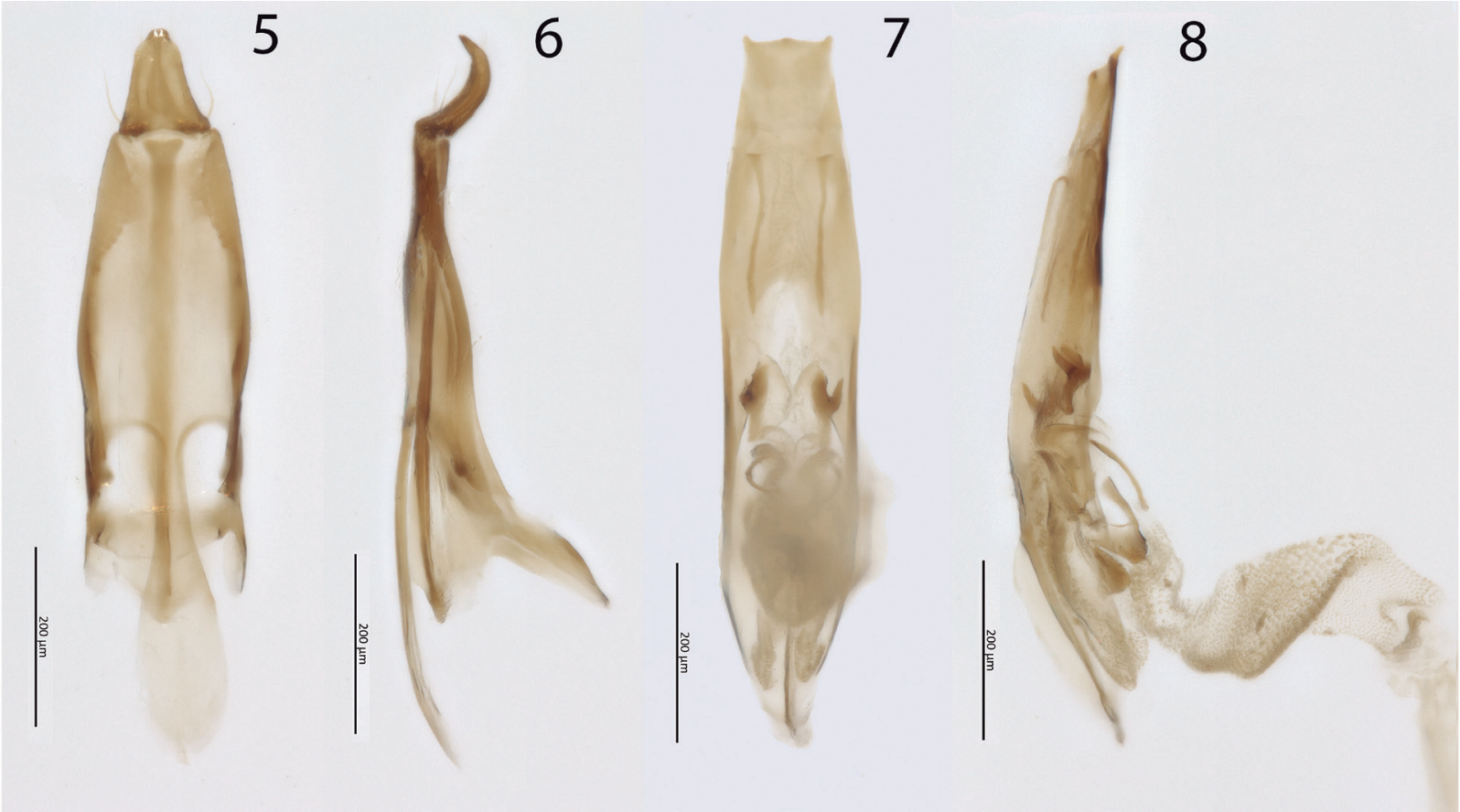

Figures 5-8. Austroporus doctus (Blackburn), male genitalia. (5) Tegmen, ventral; (6) tegmen, lateral; (7) median lobe, ventral; (8) median lobe, lateral. Scale bars: $0.2 \mathrm{~mm}$.

accessory ventral process, with two long lateral setae; apex tridentate, middle tooth most prominent, with small accessory tooth at base of ventral tooth; incisor edge with subapical row of serrations; mola sub-basal, relatively small, surface composed of a few small teeth, which do not extend onto ventral surface; inner edge without lobe or setal tuft at base of mola; prostheca absent. Ventral mouthparts (Fig. 16) protracted; cardo and stipes fused to mala; maxillary articulating area absent; stipes slightly elongate, with 2 long setae and a campaniform sensillum; mala (Fig. 11) finger-like, about as wide and as long as palp, slightly curved mesally and apically rounded, with a few stout setae, mesal surface with a distinct groove about half length of maxilla; maxillary palps (Fig. 11) well developed and 3-segmented; palpomere 1 strongly transverse, partially fused to stipes, 2 about 0.7 times as long as wide, 3 about 1.7 times as long as wide, narrowly rounded at apex. Submentum (Fig. 10) with pair of setae and pair of campaniform sensilla; ligula weakly bilobed and covered with micropapillae; labial palps (Fig. 10) 2-segmented and well separated. Hypostomal rods (Fig. 16) long and diverging, extending about two-thirds distance to occipital foramen; gula (Fig. 16) elongate, gular sutures strongly convergent anteriorly, almost meeting near base of labium, gula separated from base of labium by transverse suture. Hypopharyngeal sclerome absent; hypopharynx with central area smooth and devoid of microstructures. Tentorial bridge moderately broad, curved, with 2 slender anterior arms attached.

Thorax (Fig. 14) relatively long, about two-fifths as long as abdomen; each thoracic tergum with pair of very long setae on each side, plus two transverse rows of short setae. Legs (Fig. 16) relatively short, about as long as half width of thorax, widely separated, coxae globular, not projecting, not visible from above; pro- (Fig. 16) and mesocoxae each separated by about 2 coxal diameters, metacoxae by more than two coxal diameters; trochanter slightly longer than coxa; femur stout, parallel-sided, apically truncate, with several long setae; tibiotarsus about as long as femur, narrowed apically, with few setae; pretarsus stout, curved with acute apex, with 1 moderately long seta located near middle.

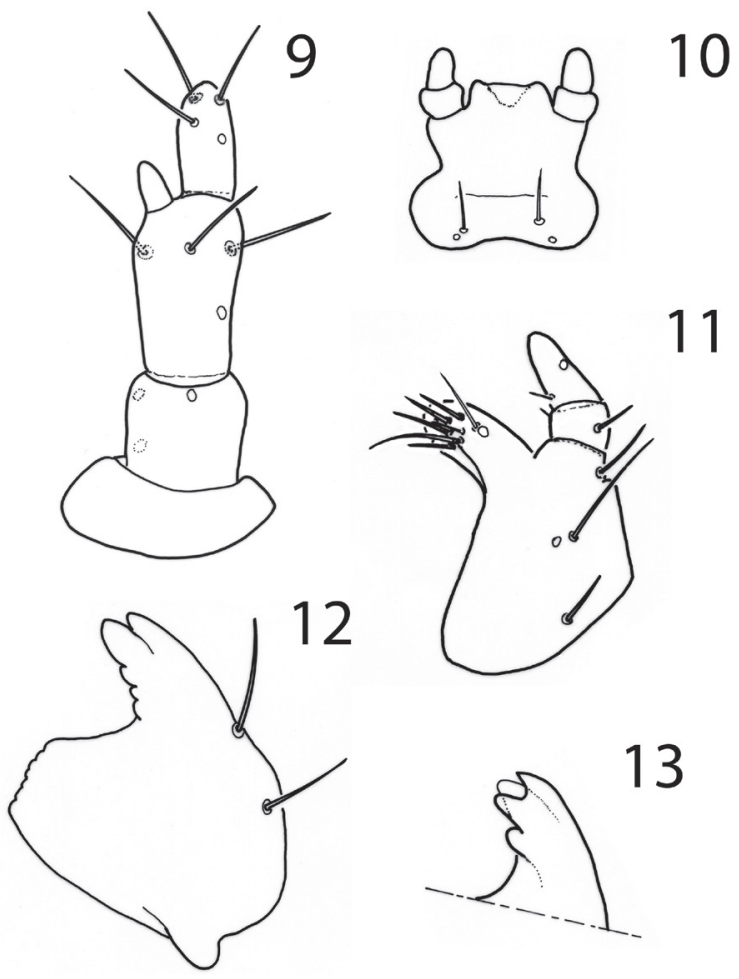

Figures 9-13. Austroporus doctus (Blackburn), larval structures. (9) Antenna, latero-ventral; (10) labium, ventral; (11) left maxilla, ventral; (12) left mandible, ventral; (13) apex of mandible, dorsal. 
Abdominal segments I-VII (Fig. 14) with tergal plates poorly defined, more or less evenly pigmented; segment VIII (Fig. 18) more strongly dorsoventrally compressed, about $1.5 \times$ longer than segment VII, both tergite and sternite VIII more strongly sclerotized at posterior margin, tergite with a small, laterally tapering apical plate extending about one-seventh length of tergite, and with depigmented middorsal line (Fig. 18); segment IX (Fig. 18) with basal portion extremely short, much shorter and more well-sclerotized than other abdominal segments, with tergum extending well onto ventral surface; apex with pair of long, stout, well-sclerotized urogomphi (Fig. 18), diffusely darker than basal part of tergum IX; urogomphi separated by a narrowly rounded emargination; urogomphus straight and gradually narrowed in basal two-thirds, more abruptly narrowed and moder- ately dorsally curved in apical one-third, urogomphus about half length of segment IX. Segment $X$ ventral, membranous and concealed. Spiracles annular-biforous with short accessory chambers and closing apparatus, mesothoracic spiracles located on weak tubercles, those on abdominal segments not borne on tubercles; spiracles on segments I-VII located above lateral tergal lobes, those on segment VIII (Fig. 18) located at posterolateral edges of tergum, facing dorsally.

Comments: We observed four stemmata, but it is possible that the anteriormost stemma (Fig. 17) represents a fusion of 2 of these, and that the true number is 5 for the species. The most recent description of the family larvae mentioned 5-6 stemmata (Lawrence et al., 2010).

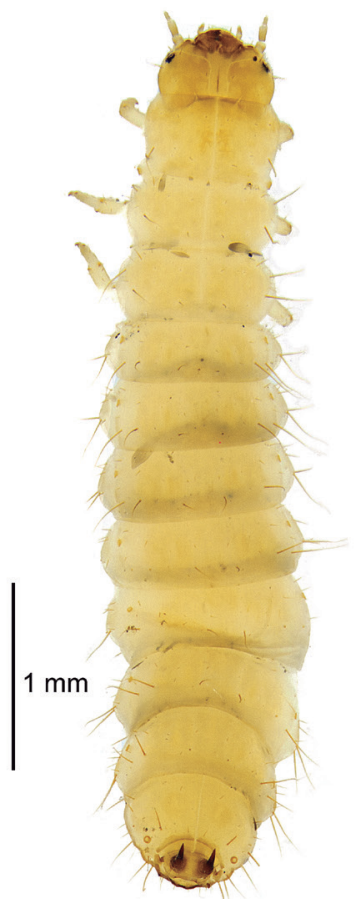

\section{4}

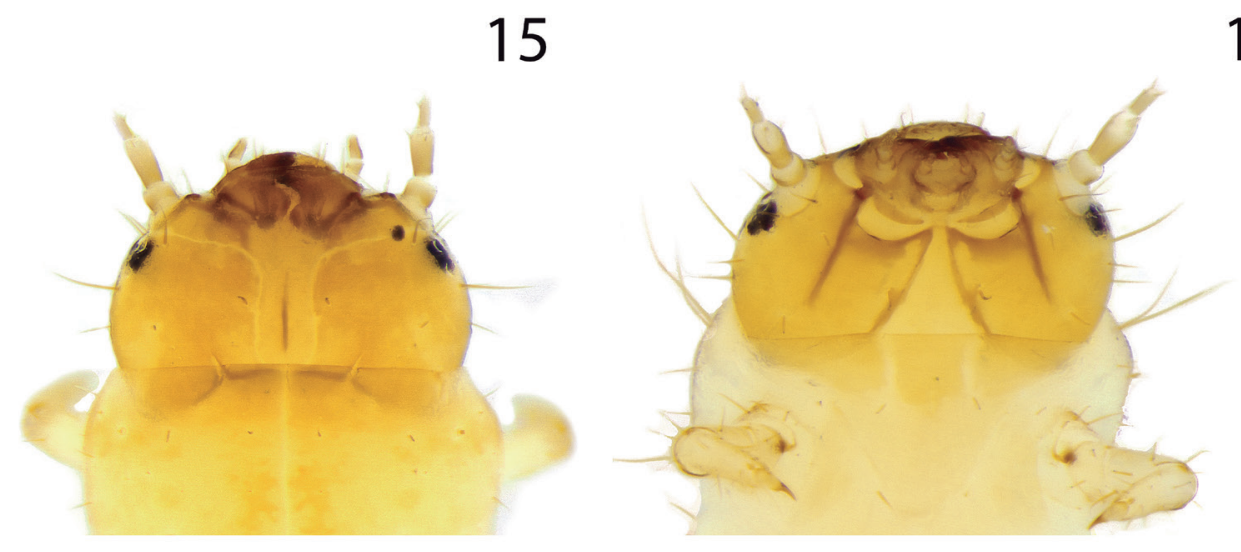

Figures 14-16. Austroporus doctus (Blackburn), larva. (14) habitus, dorsal; (15) head and prothorax, dorsal; (16) head and prothorax, ventral.
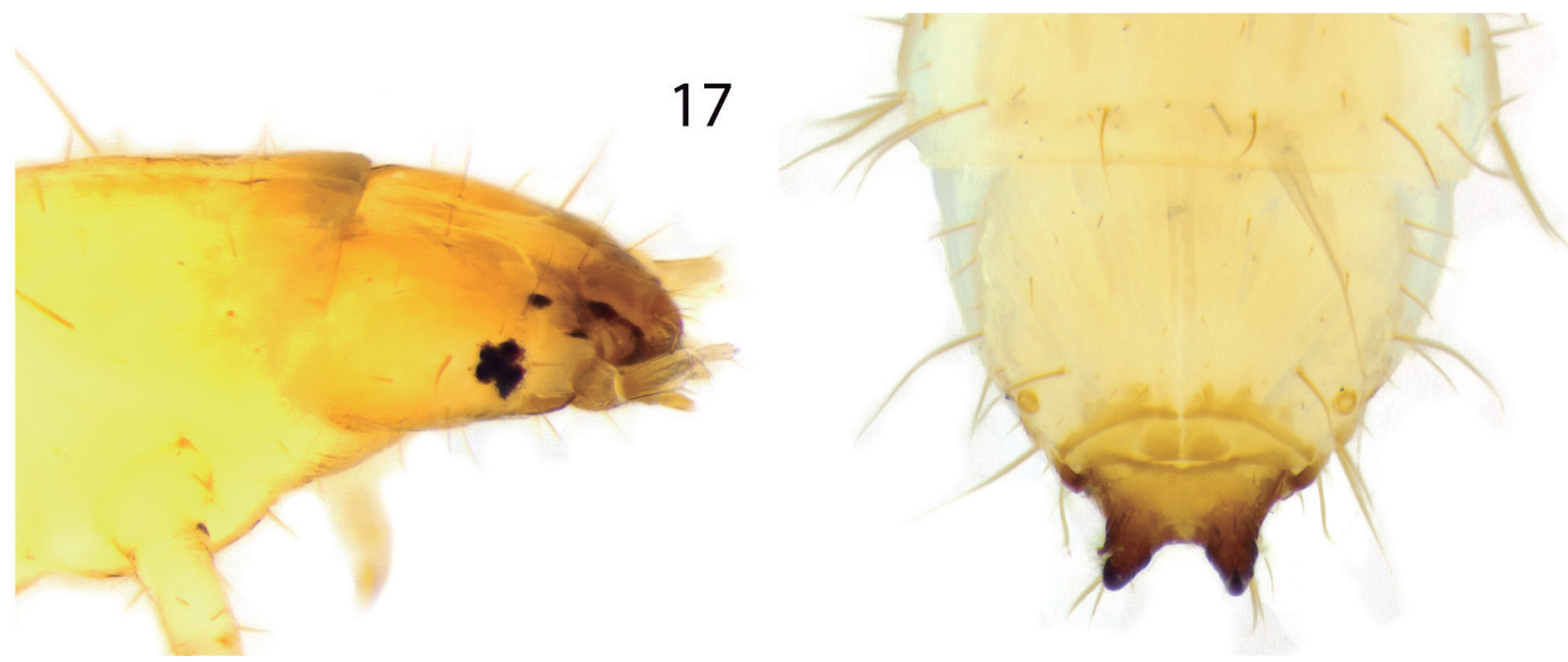

Figures 17-18. Austroporus doctus (Blackburn), larva. (17) head and prothorax, right lateral; (18) tergites VII-IX, dorsal. 
Distribution: This species was subsequently reported by Lea (1932) from numerous additional localities in New South Wales, Queensland, and Victoria, Australia. However, some of these specimens may be based on misidentifications of similar, possibly undescribed species. We have verified dissected male specimens from New South Wales and Australian Capital Territory, to as far north as Paluma, Queensland. The New Zealand specimens represent a new country record.

\section{Key to adults and larvae of New Zealand Phalacridae (some figures from Thompson \& Marshall (1980) [“TM"])}

1. Adult: antennal insertions hidden in dorsal view by continuously arcuate frontal margin of head; scutellar shield large, basal width greater than diameter of eye (TM: fig. 3); metaventral process large, protruding anteriorly, surpassing mesocoxae; elytra uniformly dark brown. Larva: antenna with sensorium present on antennomere 1 (TM: fig. 26); median endocarina absent on head (TM: fig. 24); frontal arms meeting at base, forming short epicranial stem (TM: fig. 24); head capsule elongate, narrow (TM: fig. 24)....

Phalacrus uniformis (Blackburn)

- Adult: antennal insertions exposed in dorsal view by emarginations in frontal margin of head (Fig. 4); scutellar shield (Fig. 1) small, basal width shorter than diameter of eye; metaventral process short, not protruding anteriorly, not surpassing mesocoxae (Fig. 2); elytra blackish with central reddish maculation (Figs. 1, 3). Larva: antenna with sensorium present on antennomere 2 (Fig. 9); median endocarina present on head (Fig. 15); frontal arms independently reaching posterior margin of head capsule, epicranial stem absent (Fig. 15); head capsule short, wide (Fig. 15).

. Austroporus doctus (Blackburn)

\section{Biology}

We examined a series of adult specimens of Austroporus doctus from within its native range in Australian Capital Territory, Australia (see Material Examined) that have the following label information: "sheltering and in Uromycladium galls on Acacia" and "ex Acacia melanoxylon". In New Zealand, adults of this species have been observed in the Auckland area from Acacia longifolia, and have also been seen in association with Paraserianthes lophantha (Willd.) I.C. Nielsen (Fabaceae; Alan Flynn, pers. comm.).

We were contacted by Richard Hill (Manaaki Whenua Landcare Research) to identify specimens of beetles collected during a late spring survey (11 December 2018) of invertebrates associated with of Acacia longifolia in six sites in Northland (Hill \& Dymock, 2019). Over 29\% of all invertebrates collected with a beating tray were adult or larval Austroporus. The larvae were found when seeds were stripped out of the pods, and they may feed on the aril of the seed or fungus on the aril (R. Hill, pers. comm.). Seed pods that were brought to the laboratory for observation contained larval Austroporus that were discovered inside Acacia longifolia seeds bearing holes, but the source of the holes is unknown, though presumed to be from the host-specific weevil Storeus albosignatus (Blackburn). The larval guts were empty, so feeding may not have been within the seed pods, or their primary food source had been depleted. Austroporus were abundant at some sites and not others and it was thought that the beetle was more likely to be associated with Uromycladium acaciae galls growing on black wattle (Acacia mearnsii) adjacent to some of the stands of Acacia longifolia sampled during the survey. The following season, Jenny Dymock collected adult Austroporus directly from Acacia longifolia flowers at Coopers Beach (September 2019) and we were supplied with approximately two liters of Uromycladium galls that yielded no larval or adult Austroporus.

\section{DISCUSSION}

Based on previously described material, the structural variability within larvae of Phalacridae greatly exceeds that of the adults, particularly with respect to mouthparts. Unfortunately, larvae have been fully described for members of only three genera of Phalacridae: Acylomus Sharp, Olibrus Erichson and Phalacrus Paykull. Additionally, an undetermined species of Phalacridae from Panama was described by Lawrence et al. (2013, 2019), initially misidentified as Lepiceridae (Myxophaga) but similar to specimens from Malaysia placed in Phalacridae based on CO1. From the available, identified barcode sequences in BOLD (Barcode of Life Data System; www.boldsystems.org), this larva matched most closely with Acylomus (see Lawrence et al., 2019). This genus belongs to the widespread Stilbus-group of genera (sensu Gimmel, 2013) which contains many extremely common species in both the Old World and New World. Although the Panamanian larva possesses some bizarre characteristics (e.g., the undivided, acute process on tergum IX), it is quite similar in general habitus to some active mold-grazing forms of Acylomus (e.g., A. calcaratus Casey, fig. 16.4A in Steiner, 1984). All Acylomus larvae so far studied possess a "pseudomola" on the mandible, whereas the only studied Stilbus Seidlitz species has a mandibular mola (see Steiner, 1984). The Lawrence et al. (2013) larva possesses a fully developed mola, casting doubt on the generic assignment based on CO1 (see Will et al., 2005). Generic coverage for Phalacridae is sparse on BOLD (7 of 33 genera, or 21\%), and very few of the sequenced specimens have been taxonomically verified by an expert. Moreover, worldwide generic boundaries in the Stilbus-group need additional study to confirm monophyly of its constituent genera.

In addition to the published full descriptions, certain larval characters were illustrated for Litochropus Casey, Litochrus Erichson, Phalacropsis Casey and Stilbus Seidlitz by Steiner (1984) and Lawrence (1991). No immature stages for any member of the Olibroporus-group have been described or reported. See Table 1 for a summary of prior published larval descriptions and illustrations. Note that thorough family-level descriptions may be found in Lawrence (1991), Klausnitzer (2001), and Lawrence et al. (2010). 
Table 1. Prior larval descriptions of Phalacridae.

\begin{tabular}{|c|c|c|}
\hline Taxon & Region & References \\
\hline Acylomus calcaratus Casey, 1890 & Nearctic & Steiner (1984) [habitus drawing only] \\
\hline Acylomus pugetanus Casey, 1916 & Nearctic & Steiner \& Singh (1987) \\
\hline Litochropus clavicornis Casey, 1916 & Nearctic & $\begin{array}{l}\text { Steiner (1984) [mandible drawing only]; } \\
\text { Lawrence (1991) [habitus drawing only] }\end{array}$ \\
\hline Litochrus sp. & Australian & $\begin{array}{l}\text { Lawrence (1991) [ventral head, } \\
\text { mandible, urogomphi drawings only] }\end{array}$ \\
\hline Olibrus aeneus (Fabricius, 1792) & Palearctic & $\begin{array}{l}\text { Urban (1927); Böving \& Craighead } \\
\text { (1931) }\end{array}$ \\
\hline Olibrus millefolii (Paykull, 1800) & Palearctic & Urban (1930) \\
\hline Olibrus sp. & Nearctic & Löben Sels (1934) [as Phalacrus politus] \\
\hline Phalacrinus sp. & Australian & $\begin{array}{l}\text { Lawrence \& Ślipiński (2013) [presumed } \\
\text { larva, descriptive notes only] }\end{array}$ \\
\hline Phalacropsis dispar (LeConte, 1879) & Nearctic & $\begin{array}{l}\text { Steiner (1984) [mandible drawing only]; } \\
\text { Lawrence (1991) [mandible SEMs only] }\end{array}$ \\
\hline Phalacrus caricis Sturm, 1807 & Palearctic & d'Aguilar (1944) \\
\hline Phalacrus corruscus (Panzer, 1797) & Palearctic & Friederichs (1908) \\
\hline Phalacrus grossus Erichson, 1845 & Palearctic & van Emden (1928) \\
\hline Phalacrus politus Melsheimer, 1844 & Nearctic & Böving \& Craighead (1931) \\
\hline Phalacrus uniformis (Blackburn, 1891) & Australian & Thompson \& Marshall (1980) \\
\hline Stilbus pallidus Casey, 1890 & Nearctic & Steiner (1984) [mandible drawing only] \\
\hline unknown, probably Stilbus-group & Neotropical & Lawrence et al. (2013) [as Lepicerus] \\
\hline
\end{tabular}

As mentioned above, larval phalacrids are structurally quite diverse, particularly in the shape of the mandibles. Mandibular structure, as with beetles in general, is closely correlated with feeding habits within the group, which are likewise quite diverse (Steiner, 1984). Genera that possess a larval mandibular mola include Phalacrus, Phalacropsis, Stilbus, and Austroporus. Feeding habits of these are known or presumed to be fungal spores. Genera that lack a mola but possess two or more slender, hyaline processes include Litochropus, Litochrus, and Olibrus. Members of these three genera are known to be associated with corky fungal tissue, rotten wood, and composite flower heads, respectively. Based on examination of gut contents, Litochropus feed primarily on corky fungal tissue, whereas the exact diets of Litochrus (J. Lawrence, pers. comm.) and Olibrus remain unknown. In the case of Olibrus guts so far examined (Steiner, 1984; Gimmel, pers. obs.), the diet apparently does not include pollen since solid material has never been observed in the gut. The presumed larva of Phalacrinus, collected from between joined Eucalyptus leaves on fallen twigs, has a simple mandibular base, but its diet is unknown (J. Lawrence, pers. comm.). Members of Acylomus, the only other genus whose larvae are described, possess a "pseudomola", a narrow, sub-basal mola-like structure on the mandible. These are reported to be mold-grazers or feeders within the sclerotia of ergot fungus. Despite the variability of the molar region, all known phalacrid larvae have 3-4 apical teeth of the mandible, often with short accessory teeth or serrations. For an excellent figure showing the variety of phalacrid mandibular types, see Steiner (1984: p. 441).

Phalacridae have recently (Lawrence et al., 2010) been treated with two subfamilies, Phalacrinae and Phaenocephalinae, the latter containing three genera distributed in the Old World tropics and subtropics.
However, Gimmel (2013) recognized the latter group as the monophyletic "Phaenocephalus-group" of genera, the phylogenetic analyses indicating only weak placement of Phaenocephalinae as sister group to the remaining Phalacridae, with unpublished molecular data suggesting alternate relationships. Unfortunately, larvae of the Phaenocephalus-group of genera remain undescribed. An analysis of larval character states of Phaenocephalusgroup larvae may prove highly informative of relationships within the family.

Interestingly, the mandible of the larva of Austroporus possesses subapical serrations just as in the mandible of the adult. This larval character is shared with the known larvae of Acylomus and Stilbus (including the larva first described as Lepicerus), but not with the adults of those genera.

\section{ACKNOWLEDGMENTS}

First and foremost, we are pleased to participate in this series of papers celebrating Cleide Costa. Not only do we acknowledge the mark she has left on Brazilian entomology, but we honor Cleide Costa's influential work on Coleoptera, particularly her work on larval and elateriform beetles, that forms an integral part of the canon of Coleopteran systematics and morphology.

We thank Richard Hill (Manaaki Whenua Landcare Research) for bringing these phalacrids to our attention, and Jenny Dymock for additional collecting and transport of specimens and galls, and Alan Flynn (Ministry of Plant Industry) for additional collection information. We thank John Lawrence for providing unpublished notes on Australian phalacrid larvae, Lucie Gimmel (Santa Barbara Museum of Natural History) for the adult habitus images, and Max Barclay (BMNH) for loaning the type material. Emmanuel Arriaga-Varela and Hermes Escalona significantly improved this manuscript during the review stage. MG was funded in part by the Schlinger Foundation and generous gifts from John Carson and Tom Dimock. RL was funded in part by the Strategic Science Investment Fund to Crown Research Institutes from the Ministry of Business, Innovation and Employment's Science and Innovation Group.

\section{REFERENCES}

d'Aguilar, J. 1944. Contribution à l'étude des Phalacridae: note sur Phalacrus caricis Sturm. Annales des Épiphyties et de Phytogénétique (New Series), 10: 85-91.

Blackburn, T. 1895. Further notes on Australian Coleoptera, with descriptions of new genera and species (XVIII). Transactions of the Royal Society of South Australia, 19: 201-258.

Böving, A.G. \& Craighead, F.C. 1931. An illustrated synopsis of the principal larval forms of the order Coleoptera. Entomologica Americana (N.S.), 11["1930"]: 1-351.

Emden, F. van. 1928. Die Larve von Phalacrus grossus Er. und Bemerkungen zum Larvensystem der Clavicornia. Entomologische Blätter für Biologie und Systematik der Käfer, 24: 8-20. 
Friederichs, K. 1908. Über Phalacrus corruscus als Feind der Brandpilze des Getreides und seine Entwicklung in brandigen Ähren. Arbeiten aus der Kaiserlichen Biologischen Anstalt für Land- und Forstwirtschaft, Berlin, 6: 38-52.

Gimmel, M.L. 2013. Genus-level revision of the family Phalacridae (Coleoptera: Cucujoidea). Zootaxa, 3605: 1-147.

Gimmel, M.L. 2017. Taxonomic notes on Olibroporus Casey and Pycinus Guillebeau (Coleoptera: Phalacridae), with diagnosis and distribution of the widespread species Olibroporus punctatus Casey. The Coleopterists Bulletin, 71: 61-73.

Hill, R.\& Dymock, J. 2019. Invertebrates associated with Acacia longifoliae [sic] Andr. (Willd.) [sic] (Leguminosaae) [sic] in Northland and Horowhenua. Prepared for Northland Regional Council. Available at: https://www. landcareresearch.co.nz/ data/assets/pdf file/0005/212387/finalreport-Invertebrates-associated-with-Acacia-longifoliae.pdf. Access in: 02/11/2019.

Klausnitzer, B. 2001. Die Larven der Käfer Mitteleuropas. 6. Band. Polyphaga. Teil 5. Spektrum Heidelberg/Berlin, Akademischer Verlag.

Lawrence, J.F. 1991. Phalacridae (Cucujoidea). In: Stehr, F.W. (Ed.). Immature Insects. Dubuque, Kendall/Hunt. v. 2, p. 466-468.

Lawrence, J.F. \& Ślipiński, A. 2013. Australian Beetles. Volume 1: Morphology, Classification and Keys. Collingwood, CSIRO Publishing.

Lawrence, J.F.; Gimmel, M.L. \& Steiner Jr., W.E. 2010. Phalacridae Leach, 1815. In: Leschen, R.A.B.; Beutel, R.G. \& Lawrence, J.F. (Eds.). Coleoptera, Beetles. Vol. 2: Morphology and systematics (Elateroidea, Bostrichiformia, Cucujiformia partim). Berlin, Walter de Gruyter. p.368-374. (Handbook of Zoology, Arthropoda: Insecta)

Lawrence, J.F.; Ślipiński, A.; Beutel, R.G. \& Newton, A.F. 2013. A possible larva of Lepicerus inaequalis Motschulsky (Coleoptera: Myxophaga: Lepiceridae) from Panama. Zootaxa, 3701(3): 393-400.
Lawrence, J.F.; Ślipiński, A.; Beutel, R.G. \& Newton, A.F. 2019. Lepicerus larva still unknown: a correction (Coleoptera: Lepiceridae, Phalacridae). Zootaxa, 4545(3): 441-442.

Lea, A. 1932. The Phalacridae (Coleoptera) of Australia and New Guinea. Records of the South Australian Museum, 4: 433-481.

Löben Sels, E. von. 1934. Some observations on Phalacrus politus and other inhabitants of the heads of the New England Aster. Journal of the New York Entomological Society, 42: 319-327. https://www.jstor.org/ stable/25004568.

Steiner Jr., W.E. 1984. A review of the biology of phalacrid beetles (Coleoptera). In: Wheeler, Q. \& Blackwell, M. (Eds.). Fungus-Insect Relationships: Perspectives in Ecology and Evolution. New York, Columbia University Press. p. 424-445.

Steiner Jr., W.E. \& Singh, B.P. 1987. Redescription of an ergot beetle, Acylomus pugetanus Casey, with immature stages and biology (Coleoptera: Phalacridae). Proceedings of the Entomological Society of Washington, 89: 744-758.

Thompson, R.T.\& Marshall, J.E. 1980. A taxonomic study of Phalacrus uniformis (Coleoptera: Phalacridae), an Australian beetle now established in New Zealand. New Zealand Journal of Zoology, 7: 407-416.

Urban, C. 1927.Über die Olibrus-Larve (Col. Phalacr.). Deutsche Entomologische Zeitschrift, 1926: 401-412.

Urban, C. 1930. Über die Larve des Olibrus millefolii Payk. (Col. Phalacr.). Mitteilungen der Deutschen Entomologischen Gesellschaft, 2: 39-42.

Will, K.W.; Mishler, B.D. \& Wheeler, Q.D. 2005. The perils of DNA barcoding and the need for integrative taxonomy. Systematic Biology, 54(5):844-851. DOI 